\title{
Synthesis and application of cationised cellulose for removal of Cr(VI) from acid mine- drainage contaminated water
}

\author{
Anita Etale ${ }^{\text {a1 }}$, Dineo Nhlane ${ }^{\mathrm{b}}$, Alseno K. Mosai ${ }^{\mathrm{b}}$, Jessica Mhlongo ${ }^{\mathrm{b}}$, Aaliyah Khan ${ }^{\mathrm{c}}$, Karl Rumbold ${ }^{\mathrm{c}}$, \\ Yannick Nuapia ${ }^{b}$ \\ ${ }^{a}$ Global Change Institute, University of the Witwatersrand, Johannesburg 2000, South Africa. \\ ${ }^{\mathrm{b}}$ Molecular Sciences Institute, School of Chemistry, University of the Witwatersrand, Johannesburg 2000, \\ South Africa.
}

c School of Molecular and Cell Biology, University of the Witwatersrand, Johannesburg 2000, South Africa.

\begin{abstract}
Cationised hemp cellulose was prepared by etherification with two quaternary ammonium salts: 3-chloro-2hydroxypropyl trimethyl ammonium chloride (CHPTAC) and glycidyltrimethylammonium chloride (GTMAC) and examined for (i) the efficiency of $\mathrm{Cr}(\mathrm{VI})$ removal under acid mine-drainage (AMD) conditions, and (ii) antibacterial activity. Adsorbents were characterised by electron microscopy, Fourier transform infrared (FTIR), CP-MAS ${ }^{13} \mathrm{C}$ nuclear magnetic resonance (NMR) spectroscopy, elemental composition and surface charge. FTIR and solid state ${ }^{13} \mathrm{C}$ NMR confirmed the introduction of quaternary ammonium moieties on cellulose. ${ }^{13} \mathrm{C}$ NMR also showed that cationisation decreased the degree of crystallisation and lateral dimensions of cellulose fibrils. Nevertheless, $47 \%$ $72 \%$ of $\mathrm{Cr}(\mathrm{VI})$ ions were removed from solutions at $\mathrm{pH} 4$, by $0.1 \mathrm{~g}$ of CHPTAC and GTMAC-cationised cellulose, respectively. Adsorption kinetics followed the pseudo-second order model and isotherms were best described by the Freundlich and Dubinin-Radushkevich models. When GTMAC-modified cellulose was applied to AMD contaminated water ( $\mathrm{pH}$ 2.7), however, $\mathrm{Cr}(\mathrm{VI})$ uptake removal decreased to $22 \%$ likely due to competition from $\mathrm{Al}$ and $\mathrm{Fe}$ ions. Nevertheless, cationised materials displayed considerable antibacterial effects, reducing the viability of Escherichia coli by up to $45 \%$ after just 3 hours of exposure. Together, these results suggest that cationised cellulose can be applied in the treatment of $\mathrm{Cr}(\mathrm{VI})$-contaminated mine water particularly if pre-treatments to reduce $\mathrm{Fe}$ and $\mathrm{Al}$ concentrations are applied.
\end{abstract}

Key words: Cellulose cationisation, Chromium(VI), acid mine drainage, hemp cellulose, glycidyltrimethylammonium chloride, 3-chloro-2-hydroxypropyl trimethyl ammonium chloride, quaternary ammonium salts

\section{Introduction}

Acid mine drainage represents a major source of water contamination in regions of previous mining activity (McCarthy, 2010; Naicker et al., 2003). A number of processes are responsible for this contamination, most notably the weathering of waste piles and leaching of toxic ions through these piles into groundwater, or surface run-off of to surface water bodies (Tutu, 2006). Concentrations as high as $152 \mathrm{mg} \mathrm{kg}^{-1}$ of chromium have been reported in fly ash (Saha et al., 2011), which is thought to be responsible for the elevated chromium levels of soils around coal-fired power plants. Although it exists as the relatively immobile $\mathrm{Cr}$ (III) under reducing conditions, oxidising conditions are characterized by highly mobile $\mathrm{Cr}(\mathrm{VI})$ which is classified as a carcinogen. As such, the WHO limits for chromium in drinking water are set at $50 \mu \mathrm{g} \mathrm{L}^{-1}$ (WHO, 2003).

\footnotetext{
${ }^{1}$ Corresponding author: aetale@gmail.com
} 
A number of approaches exist for the removal of $\mathrm{Cr}(\mathrm{VI})$ from water, including oxidation-reduction reactions with iron oxides (Johnston and Chrysochoou, 2012; Liu et al., 2018), electrocoagulation (Martín-Domínguez et al., 2018), ion exchange (Kabengi et al., 2017). Reverse osmosis and nanofiltration membranes have also been explored for $\mathrm{Cr}$ removal from drinking water (Anand et al., 2018). However, as is common with membrane technologies, fouling and high investment and operational costs present a significant barrier to wide-spread adoption.

Adsorption-based approaches are attractive for a wide range of reasons including cost-effectiveness, reusability, the possibility to apply a wide range of adsorbents, and to increase their efficiency and specificity by functionalisation with appropriate moieties (Benhamou et al., 2014; Dindar et al., 2015; Etale et al., 2020, 2015, 2014; Nhlane et al., 2020; Zou et al., 2011). A wide range of adsorbents including iron oxides, porous silica, and zeolites have been shown to be effective for the treatment of water contaminated by chromium(Benhamou et al., 2013; Fellenz et al., 2017; Liu et al., 2018; Pour et al., 2015; Sannino et al., 2009; Smith and Ghiassi, 2006). In recent years, there has been shifting away from simply providing solutions, to doing so in ways that are cleaner, greener, and more affordable. Besides ensuring that solutions do not create new problems e.g. new classes of environmental pollutants, this approach can also lead to exploitation of locally-available resources, thus generating affordable solutions.

Cellulose is the most abundant natural polymer, given that it makes up a considerable fraction of the structure of plants (Foster et al., 2018). With an annual production of over 7 billion kilograms (Garside, 2020), cellulose is considered an inexhaustible source of environmentally-friendly raw materials (Klemm et al., 2005). For the production of lowcost products, however, it is important that locally available materials, including waste materials are explored as these are often abundant and lower in cost. The extraction of cellulose from agricultural wastes including sugarcane bagasse, wheat and rice straw, jute and hemp fibres, as well as pineapple and palm leaves has been reported (Cherian et al., 2010; El Achaby et al., 2018; Kassab et al., 2020a, 2020b, 2019; Mandal and Chakrabarty, 2011; Rashid and Dutta, 2020; Silvério et al., 2013). The application of cellulose from these waste materials for water treatment is of increasing scientific interest due to the potential affordability of adsorbent materials. Once extracted, cellulose fibres can be oxidized to imbue them with negative surfaces suitable for cation adsorption (Beck et al., 2015; Besbes et al., 2011; Eyley and Thielemans, 2014; Gorgieva et al., 2019; Zhao et al., 2017), or cationised to allow for the adsorption of anions (Hashem and El-Shishtawy, 2001; Udoetok et al., 2016a, 2016b).

A common cationization approach involves the use of quaternary ammonium salts. Traditionally performed to improve dye retention of fibres (Acharya et al., 2014; Alebeid and Zhao, 2016), cationization has also been used in liquid-liquid extraction of chromium from water (Wang et al., 2011), and to improve the performance of adsorbents for water treatment. Peat modified with glycidyltrimethylammonium chloride was shown to increase removal of phosphate and sulphate ions due to the increase in positive surface charges on the adsorbent from protonated amines (Gogoi et al., 2019; Sehaqui et al., 2016). Cationization was also reported to improve the dispersion and stability of cellulose fibres in water (Zaman et al., 2012). For water treatment, cationised adsorbents proffer additional benefits due to their antibacterial properties. Polyvinyl films with GTMAC were found to be active against both Gram-positive (Staphylococcus aureus and Bacillus subtilis) and Gram-negative (Escherichia coli and Pseudomonas aeruginosa) bacteria (Pour et al., 2015). Cationization can also increase antibacterial activity by providing anchorage for other antibacterial agents e.g. silver nanoparticles (Shateri Khalil-Abad et al., 2009).

We investigated the cationization of cellulose fibres derived from hemp plants. Hemp represents an increasingly available feedstock for cellulose production in South Africa due to recent legalization of its cultivation for medicinal use. After extraction of oil from seeds, other plant parts including stems and branches are unused and provide a valuable source of cellulose. Cellulose was extracted via alkali treatment and cationised using two quaternary ammonium salts: 3-chloro-2-hydroxypropyl trimethyl ammonium chloride, and glycidyltrimethylammonium chloride. The efficiency of adsorbents for the removal of $\mathrm{Cr}(\mathrm{VI})$ ions was investigated at $\mathrm{pH} 4$ in order to establish adsorbent efficiencies under mine drainage conditions. As surface water is often also contaminated by biological agents, the antibacterial activity of the adsorbents was quantified. 


\section{Experimental}

\subsection{Materials}

All chemicals used were of analytical grade. 3-chloro-2-hydroxypropyl trimethylammonium chloride (CHPTAC; 60 $\mathrm{wt} \%$ in $\mathrm{H}_{2} \mathrm{O}, \mathrm{Mw}=188.10$ ), and glycidyltrimethylammonium chloride (GTMAC; $>90 \mathrm{wt} \%$ in $\mathrm{H}_{2} \mathrm{O}, \mathrm{Mw}=151.63$ ), dipotassium chromate $\left(\mathrm{K}_{2} \mathrm{CrO}_{4}\right)$, L-glutathione reduced $(\mathrm{Mw}=307.32)$, 5,5'-Dithiobis(2-nitrobenzoic acid) (Ellman's reagent), Tris- $\mathrm{HCl}$ buffer, $\mathrm{Na}_{2} \mathrm{HPO}_{4} .7 \mathrm{H}_{2} \mathrm{O}, \mathrm{NaH}_{2} \mathrm{PO}_{4} \mathrm{H}_{2} \mathrm{O}$, and $\mathrm{NaCl}$ were from Sigma Aldrich (South Africa). Tetrahydrofuran (THF, $99.5 \%$ purity) was from Merck (Germany). Hydrochloric acid (HCl, $32 \%$ ), nitric acid $\left(\mathrm{HNO}_{3}, 55 \%\right.$, sodium hydroxide $(\mathrm{NaOH})$, sodium chlorite $\left(\mathrm{NaClO}_{2}\right)$, glacial acetic acid $\left(\mathrm{CH}_{3} \mathrm{COOH}\right)$ were from Ace Chemicals (South Africa). Dry hemp branches from which fibres were obtained were sourced locally. All solutions were prepared with double deionised water with a resistivity of $18.2 \mathrm{M} \Omega \mathrm{cm}^{-1}$. Glassware and polypropylene vials were washed, soaked in a $1 \mathrm{M} \mathrm{HNO}_{3}$ acid bath for at least 24 hours, and rinsed with deionised water before use.

\subsection{Extraction of cellulose fibres}

Cellulose fibres were extracted from dried stems and branches of Cannabis sativa plants. The stems and branches were soaked in water overnight and the fibres peeled off the woody cores. They were then subjected to alkali treatment using $4 \mathrm{wt} \% \mathrm{NaOH}$ at $80^{\circ} \mathrm{C}$ in three treatment rounds, each lasting 2 hours. The cellulose microfibers obtained were bleached using equal parts of $\mathrm{NaClO}_{2}(1.7 \mathrm{wt} \%)$ and acetate buffer $(\mathrm{pH} 4.8)$ prepared from $27 \mathrm{~g}$ $\mathrm{NaOH}$ and $75 \mathrm{~mL}$ glacial acetic acid, diluted to $1 \mathrm{~L}$. Three, hour long, bleaching rounds were performed. The ratio of fibre to liquor was maintained at 1:20 for each bleaching round. The extracted cellulose was then washed with deionised water several times and dried at ambient temperature.

\subsection{Cationization of cellulose adsorbents}

Dried cellulose was cationised according to the procedure described by Odabas and colleagues (Odabas et al., 2016). Briefly, $5 \mathrm{~g}$ of cellulose fibres were added to $225 \mathrm{~mL}$ THF in a two-necked round-bottom flask equipped with a condenser, and stirred for 1 hour at ambient temperature $\left(21 \pm 2{ }^{\circ} \mathrm{C}\right) . \mathrm{NaOH}(2.5 \mathrm{~mL}, 10 \mathrm{M})$ was then added and the mixture stirred for 30 minutes, after which $17.8 \mathrm{~mL}$ of CHPTAC or GTMAC was added dropwise, and the etherification reaction allowed to proceed for 15 hours at $40{ }^{\circ} \mathrm{C}$. Afterwards, the reaction was stopped by the addition of $4 \mathrm{M} \mathrm{HCl}(12.5 \mathrm{~mL})$. The cationization solution was decanted, the fibres washed severally in ultrapure water until the $\mathrm{pH}$ of wash solutions was stable. Fibres were then dried in the oven at $45^{\circ} \mathrm{C}$ prior to characterisation and use in experiments.

\subsection{Characterisation of cationised cellulose adsorbents}

The morphology of cationised fibres was evaluated by field-emission scanning electron microscopy (FESEM). For this, the fibres were mounted on a stub with double-sided tape and sputter-coated with gold and palladium before being examined using a Zeiss Sigma 300 FESEM (Jena, Germany). The chemical structure of cellulose, before and after cationization was determined by FTIR and ${ }^{13} \mathrm{C}$ NMR spectroscopy. FTIR spectra were recorded in the range $4000-500 \mathrm{~cm}^{-1}$ in the absorption mode using a Tensor 27 Infrared Spectrometer (Massachusetts, USA).

Solid-state NMR experiments were performed with a Bruker Avance III spectrometer (500 MHz Bruker-BioSpin, $\mathrm{GmbH}$, Rheinstetten, Germany) with a $4 \mathrm{~mm}$ solids probe. The ${ }^{13} \mathrm{C}$ MAS Spectra were recorded at $125.77 \mathrm{MHz}$ at room temperature with a contact time for cross-polarization at $2 \mathrm{~ms}$ and a recycle delay of $5 \mathrm{~s}$. The chemical shifts were calibrated using adamantane as an external chemical shift reference. Spectra were recorded after scans ranging 
from 1688 (pure cellulose), to 3,810 (GT-cellulose) and 4125 (CH-cellulose). Peak deconvolution was performed using MestReNova software (version 0.0.1).

The $\mathrm{pH}_{\mathrm{PZC}}$ of cellulose and derivatives was determined by salt titration method (Udoetok et al., 2016a). For this, a $0.01 \mathrm{M} \mathrm{NaCl}$ solution was prepared and $25 \mathrm{~mL}$ aliquots transferred to five polypropylene tubes. The $\mathrm{pH}$ of these solutions was then adjusted between 2 and 10 using $0.1 \mathrm{M} \mathrm{NaOH}$ and $0.1 \mathrm{M} \mathrm{HNO}_{3}$ so that each tube had a different $\mathrm{pH}$ value. Cellulose and cationised derivatives $(0.1 \mathrm{~g})$ were then added to the $\mathrm{NaCl}$ solutions and suspensions equilibrated on a horizontal shaker for 48 hours. The final $\mathrm{pH}$ of each solution was plotted against the initial $\mathrm{pH}$ of the solutions and the $\mathrm{pH}$ PZC for each material determined from intersection points.

The elemental composition of the cationised cellulose was determined at a temperature $>1000{ }^{\circ} \mathrm{C}$ using a Vario EL Cube elemental analyser (Elementar Analysesysteme, Langenselbold, Germany).

\subsubsection{Degree of Substitution (DS)}

The degree of substitution was calculated from the nitrogen content as determined by elemental analysis using the Equation 1 (Zaman et al., 2012):

$D S=\frac{162 \times N \%}{1400-(M w \times N \%)}$

Where, 162 is the molecular weight of anhydroglucose unit, $\mathrm{N} \%$ is the proportion of nitrogen in CH-cellulose or GTcellulose, and $M w$ is the molecular weight of the cationisation agent (151.63 and 188.10 for GTMAC and CHPTAC, respectively).

\subsubsection{Crystallinity indices and lateral dimensions}

The crystallinity indices (CrI) of unmodified cellulose and cationised derivatives were calculated from the areas of the crystalline and amorphous regions of C-4 using Equation 2 (Newman, 1999).

CrI $=\frac{\text { Area of crystalline region of } C-4}{\text { Area of crystalline }+ \text { amorphou regions of } C-4} \times 100$

Lateral dimensions $(L)$ were determined after spectral deconvolution using Equation 3 (Newman, 1999) in which $h$ is the thickness of a cellulose chain, determined to be $0.57 \mathrm{~nm}$ (Sugiyama et al., 1991).

$L=\frac{2 h}{1-\sqrt{X}}$

$X$ is the ratio of the crystalline fraction of C-4 i.e.

$$
X=\frac{\text { Area of crystalline region of } C-4}{\text { Area of crystalline }+ \text { amorphous regions of } C-4}
$$

\subsection{Adsorption experiments}

The $\mathrm{Cr}(\mathrm{VI})$ removal efficiencies of cationised cellulose were determined by batch experiments at $\mathrm{pH}$ 4. To determine the optimal adsorbent mass for experiments, varying masses of $\mathrm{CH}$-cellulose and GT-cellulose (3 $120 \mathrm{mg}$ ) were added into $50 \mathrm{~mL}$ polypropylene tubes containing $20 \mathrm{~mL} \mathrm{Cr}(\mathrm{VI})$ solutions $\left(0.381 \mathrm{mg} \mathrm{L}^{-1}\right)$, and the tubes shaken on a horizontal rotary shaker at ambient temperature $\left(21 \pm 2{ }^{\circ} \mathrm{C}\right)$ for 24 hours. Adsorption kinetics were determined by monitoring $\mathrm{Cr}(\mathrm{VI})$ uptake from solutions at various time (5 - 240 minutes) while isotherms were determined after exposing adsorbents to $\mathrm{Cr}(\mathrm{VI})$ solutions of concentrations ranging from $0.06-0.29 \mathrm{mg} \mathrm{L}^{-}$ 1 . At the end of reactions, adsorbents were separated from solutions by centrifugation and the supernatants were filtered through $0.22 \mu \mathrm{m}$ poly(vinylidene difluoride) (PVDF) syringe filters. The filtrates were then acidified 
using $5 \% \mathrm{HNO}_{3}$ and stored at $4{ }^{\circ} \mathrm{C}$ before analysis by inductively-coupled plasma-mass spectroscopy (ICP-MS, Nexion 2000, Perkin Elmer, South Africa).

$\mathrm{Cr}(\mathrm{IV})$ equilibrium adsorption efficiencies of the adsorbents $\left(q_{\mathrm{e}}\left(\mathrm{mg} \mathrm{g}^{-1}\right)\right.$ were then calculated using Equation 5:

$q_{e}=\frac{C_{o}-C_{e}}{m} \times V$

Where, $C_{0}$ and $C e$ are the initial and final concentration of $\mathrm{Cr}(\mathrm{VI})$ in solution $\left(\mathrm{mg} \mathrm{L}^{-1}\right)$, respectively, $V$ is the volume of the solution (L) and $m$ is the weight of the adsorbent $(\mathrm{g})$.

\subsection{Application to real mine water}

To determine the applicability of adsorbents to actual mine water samples, $0.1 \mathrm{~g}$ of each adsorbent was contacted with AMD-contaminated water $(20 \mathrm{~mL}, \mathrm{pH} 2.7)$, on a horizontal rotary shaker, for 4 hours (Previous experiments had shown this duration to be sufficient for equilibrium). After this time, they were centrifuged, filtered and acidified and stored at $4{ }^{\circ} \mathrm{C}$ before analysis. $\mathrm{Cr}(\mathrm{VI})$ concentrations in raw and treated water were determined by ICP-MS.

\subsection{Antibacterial activity assay}

\subsubsection{Cell preparation}

The antibacterial activities of the cationised adsorbents were determined by two approaches: cell viability and glutathione oxidation, using Escherichia coli as a model bacterium. E. coli cells were grown in Luria-Bertani broth at $37{ }^{\circ} \mathrm{C}$ with constant agitation. Cells were harvested in the mid-exponential phase, centrifuged at 11,200 rpm for 1 minute and washed three times with sterile saline solution $(0.9 \% \mathrm{NaCl})$. Bacterial cell suspensions were then diluted to obtain cell samples containing 106 to $107 \mathrm{CFU} \mathrm{mL}^{-1}$.

\subsubsection{Cell viability tests}

Viability tests were conducted by incubating $E$. coli cells with unmodified and cationised cellulose (CH-cellulose and GT-cellulose) for 3 hours at room temperature $\left(26^{\circ} \mathrm{C}\right)$. Suspensions were then used to create a series of dilutions that were plated and incubated at $37{ }^{\circ} \mathrm{C}$ overnight. Cells in isotonic saline solution but no cellulose materials was used as a control. The loss of viability of bacterial cells was determined by the colony counting method and calculated using the following equation:

Loss of viability $=\frac{\text { Counts of control-Coun of sample }}{\text { Counts of control }} \times 100$

\subsubsection{Glutathione oxidation tests}

Strands of unmodified and cationised cellulose were placed into separate petri dishes containing $10 \mathrm{~mL}$ of 50 $\mathrm{mM}$ bicarbonate buffer $(\mathrm{pH} 8.6)$ and L-glutathione reduced $(4 \mu \mathrm{L}, 0.4 \mathrm{mM})$. The control contained the bicarbonate with the glutathione only. The petri dishes were then placed in a dark conditioned room at ambient temperature $\left(26^{\circ} \mathrm{C}\right)$ and shaken at $36 \mathrm{rpm}$ for 3 hours. After this time, the suspension was filtered using a 0.45 $\mu \mathrm{m}$ poly(ether sulfone) syringe filters and the filtrate divided into four $15 \mathrm{~mL}$ Falcon tubes. Next, Tris- $\mathrm{HCl}$ buffer $(1.57 \mathrm{~mL}, 1 \mathrm{M}, \mathrm{pH} 8.3)$ and Ellman's reagent $(30 \mu \mathrm{L}, 100 \mathrm{mM})$ were added aliquots of the filtrate (900 $\mu \mathrm{L}$ ) in $15 \mathrm{~mL}$ Falcon tubes, in duplicate. Glutathione loss was then determined using from absorbances recorded on a spectrophotometer at $\lambda=412 \mathrm{~nm}$, using Equation 7 :

$\%$ Glutathione loss $=\frac{\text { Absorbance of Control-Absorban of Sample }}{\text { Absorbance of Control }} \times 100$ 


\section{Results and discussion}

\subsection{Characterisation}

In this work cellulose fibres extracted from hemp plants were cationised using CHPTAC and GTMAC, and $\mathrm{NaOH}$ as a catalyst as shown in Scheme 1. Cationization using CHPTAC proceeds in two steps: (a) the conversion of CHPTAC to 2,3-epoxypropyl trimethyl ammonium chloride (EPTMAC), which then reacts with cellulose fibres to generate cationised cellulose. Cationisation using GTMAC, on the other hand, proceeds in a more straightforward manner with no intermediate compounds. Nevertheless, both approaches involve reaction of the hydroxyl groups on the cellulose fibres with the epoxide ring of CHPTAC and GTMAC, leading to the grafting of quaternary ammonium salt moieties onto the cellulose fibres. Importantly, in both approaches, care must be taken to limit hydrolysis reactions as these reduces the efficiency of cationization. Because side reactions are promoted by the presence of water (Zaman et al., 2012), THF was used as a solvent. Odabas et al (Odabas et al., 2016) showed that THF plays a "spectator" role, having little if any influence on the cationisation reaction.<smiles>C[N+](C)(C)CC(O)CCl</smiles>

3-chloro-2-hydroxypropyl trimethyl ammonium chloride (CHPTAC)

$[\mathrm{NaOH}]$

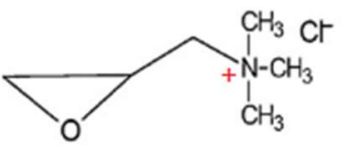

Epoxypropyl trimethyl ammonium chloride

(EPTMAC)

Cellulose in THF,

$40 \mathrm{C}, 15 \mathrm{hrs}$

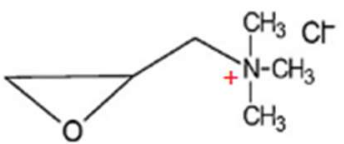

Glycydyl trimethyl ammonium chloride (GTMAC)
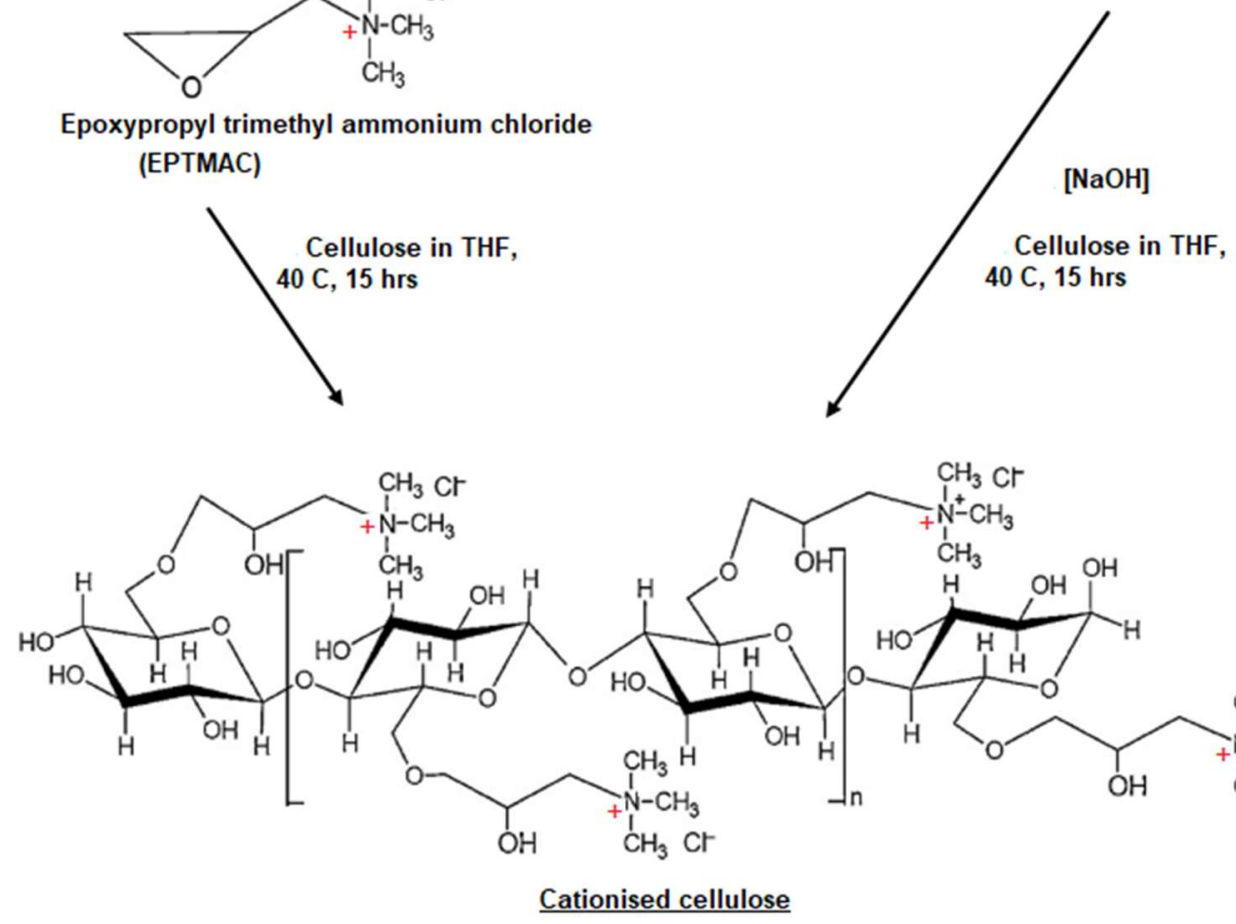

Scheme 1: Schematic representation of cellulose cationization by CHPTAC and GTMAC 
Scanning electron micrographs are presented in Figure 1. They show that both $\mathrm{CH}$-cellulose and GT-cellulose adsorbents comprised assemblies of tangled fibres of varying dimensions. It was not possible, however, to determine fibril lengths from TEM as the fibril were entangled.
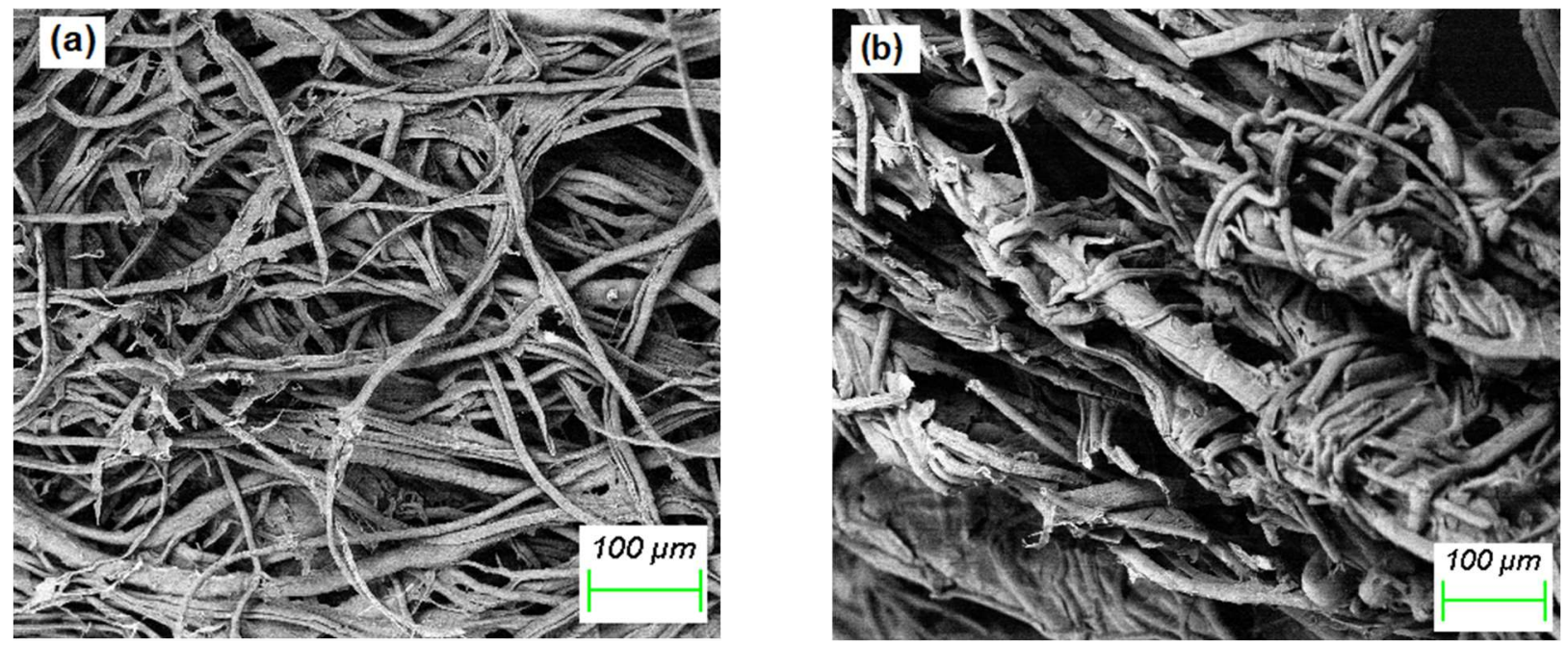

Figure 1: Scanning electron micrographs of (a) $\mathrm{CH}$-cellulose. GT-cellulose were morphologically similar.

FT-IR spectra of plain and cationised cellulose are shown in Figure 2. Characteristic absorption bands appeared in the spectra of both CH-Cellulose and GT-Cellulose at $\sim 3300$ and $2902 \mathrm{~cm}^{-1}$ due to O-H and C-H moieties of cellulose, as well as at $\sim 1644 \mathrm{~cm}^{-1}$ due to adsorbed water. However, the spectra of GTMAC-modified cellulose showed additional bands at 1056 and $1100 \mathrm{~cm}^{-1}$ due to ether linkages formed between cellulose C- 6 and the epoxy ring of the quaternary ammonium ion (see Scheme 1). A strong band at $1480 \mathrm{~cm}^{-1}$ due to symmetric bending modes of the methyl groups of GTMAC was also observed (Pour et al., 2015; Zaman et al., 2012).
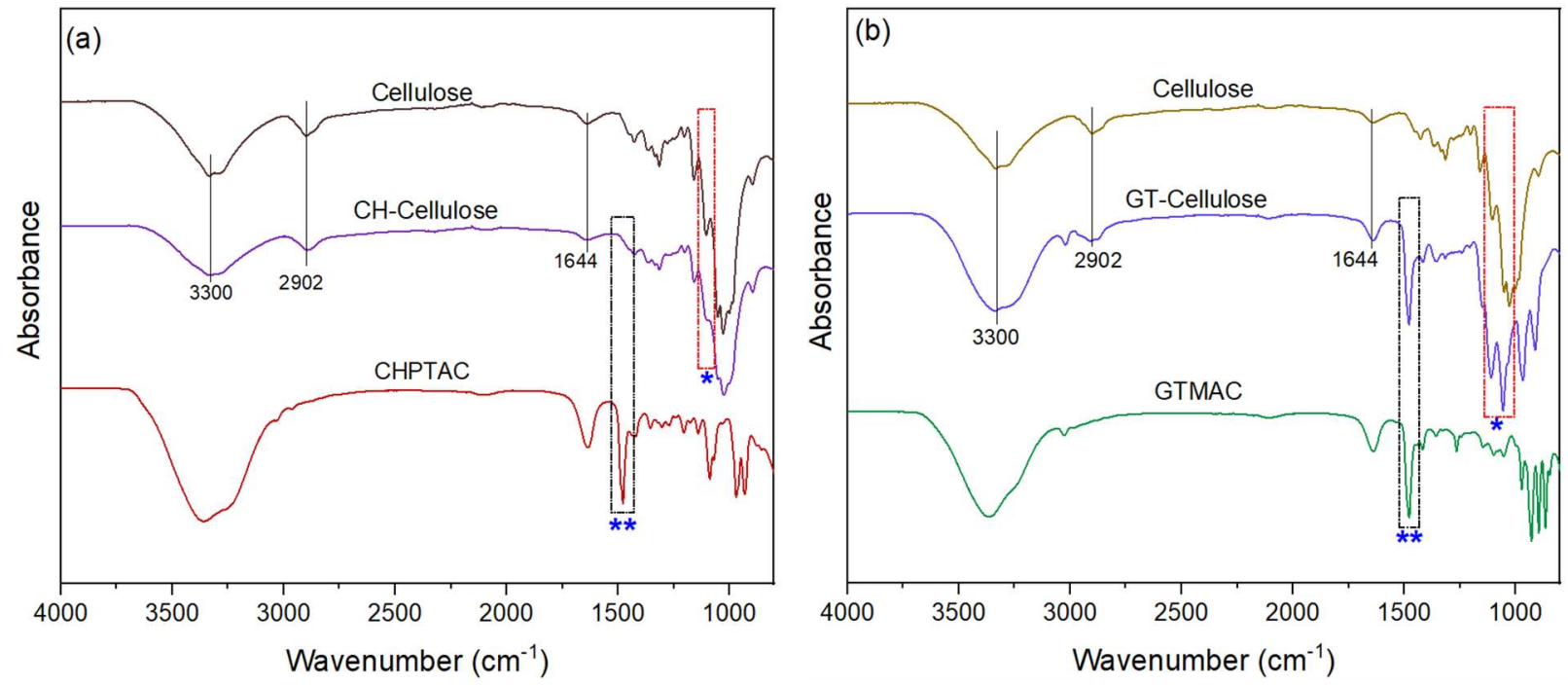

Figure 2: FTIR spectra of adsorbents before and after cationization with (a) CHPTAC and (b) GTMAC. Regions marked with a single asterisk $\left(1056 \mathrm{~cm}^{-1}\right.$ and $\left.1100 \mathrm{~cm}^{-1}\right)$ represent ether linkages between cellulose C-6 and quaternary ammonium salts (see Scheme 1) while regions marked with two asterisks $\left(1480 \mathrm{~cm}^{-1}\right)$ are due to vibrations of methyl groups of quaternary ammonium moieties. 
In contrast, an absorption band was not apparent at $1480 \mathrm{~cm}^{-1}$ in the spectra of $\mathrm{CH}$-cellulose, and bands due to ether linkages were weaker than those seen in GT-cellulose spectra. This suggests that cationisation was much less with CHPTAC than with GTMAC. Indeed, calculations of the degree of substitution showed that the nitrogen content of $\mathrm{CH}$-cellulose was $\sim 21$ times lower than that of GT-cellulose (Table 1). We surmise that IR absorption of the ether bonds and methyl groups was below the limits of detection for FTIR. Nevertheless, elemental analysis confirmed the presence of amine groups in $\mathrm{CH}$-cellulose.

Table 1: Elemental composition, degree of substitution, and $\mathrm{pH}_{\mathrm{PZC}}$ values for unmodified cellulose and cationised derivatives.

\begin{tabular}{lllllll}
\hline & $\mathbf{N ~ ( \% )}$ & $\mathbf{C ~ ( \% )}$ & $\mathbf{H ~ ( \% )}$ & $\mathbf{S ~ ( \% )}$ & $\mathbf{D S}$ & $\mathbf{p H}$ PZC \\
\hline Unmodified cellulose & 0.03 & 45.89 & 7.53 & 0.01 & - & 5.6 \\
CH-Cellulose & 0.18 & 44.20 & 7.35 & 0.03 & 0.02 & 4.2 \\
GT-Cellulose & 3.85 & 52.29 & 10.70 & 0.05 & 0.50 & 7.4 \\
\hline
\end{tabular}

The CP-MAS ${ }^{13} \mathrm{C}$ NMR spectra of cellulose extracted from hemp fibres, and cationised derivatives are presented in Figure 3. Unmodified cellulose had spectra typical of cellulose I allomorph (Table 2) (Newman, 1999; Wickholm et al., 1998). The resonances at 102-103 ppm were assigned to C-1 carbons while those at 80-86 ppm were from C-4 glycosidic bond carbons. The resonances observed at $68-73$ ppm are from C-2, C-3, and $\mathrm{C}-5$ of the pyranoid ring while those at $59-63 \mathrm{ppm}$ are from C-6 carbons. Cationised celluloses had a new peak at $\sim 52 \mathrm{ppm}$ from $\left(\mathrm{CH}_{3}\right)_{3} \mathrm{~N}^{+}$- groups of the quaternary amines, confirming the incorporation of CHPTAC and GTMAC in the cellulose structure as shown in Scheme 1.

With respect to crystallinity of cellulose I, the C-4 region of the NMR spectrum is the most informative (Wickholm et al., 1998). The broad peak represents the amorphous region while the sharp peak represents the crystalline region. Cationised derivatives had lower crystallinity indexes compared to the parent cellulose (Table 2). This was due to a decrease in the ratio of crystalline to amorphous regions from $\sim 1$ in the parent cellulose to 0.8 in GT-cellulose and 0.7 in $\mathrm{CH}$-cellulose. The lateral dimensions also followed a similar trend, decreasing from $3.88 \mathrm{~nm}$ in unmodified cellulose, to $3.08 \mathrm{~nm}$ (CH-cellulose). Cationisation therefore decreased fibril diameter. We posit that reaction with $\mathrm{NaOH}$ during cationisation broke down the amorphous regions of cellulose fibres further, reducing fibril dimensions. Similar findings were reported by Heux and colleagues for sugar beet cellulose (Heux et al., 1999).

Table 2: ${ }^{13} \mathrm{C}$ CP-MAS NMR chemical shift assignments (in ppm), crystallinity indexes $(C I)$, and lateral dimensions $(L)$ of cellulose and cationised derivatives

\begin{tabular}{|c|c|c|c|c|c|c|c|c|c|c|}
\hline \multirow{3}{*}{$\begin{array}{l}\text { Sample } \\
\text { Cellulose }\end{array}$} & \multicolumn{8}{|c|}{ Chemical shift (ppm) } & \multirow{3}{*}{$\frac{C I(\%)}{50}$} & \multirow{3}{*}{$\begin{array}{c}\boldsymbol{L} \mathbf{( n m )} \\
3.88\end{array}$} \\
\hline & \multicolumn{2}{|c|}{$\mathrm{C}-1$} & \multicolumn{2}{|c|}{$\mathrm{C}-2,3,5$} & \multicolumn{2}{|c|}{$\mathrm{C}-4$} & \multicolumn{2}{|c|}{$\mathrm{C}-6$} & & \\
\hline & 103.57 & 102.26 & 73.16 & 69.42 & 86.96 & 81.77 & 63.21 & 60.28 & & \\
\hline CH-Cellulose & 102.76 & 101.39 & 72.10 & 68.57 & 85.86 & 81.01 & 62.40 & 59.58 & 40 & 3.08 \\
\hline GT-Cellulose & 102.80 & 101.41 & 72.07 & 68.58 & 85.90 & 80.99 & 62.41 & 59.47 & 44 & 3.42 \\
\hline
\end{tabular}




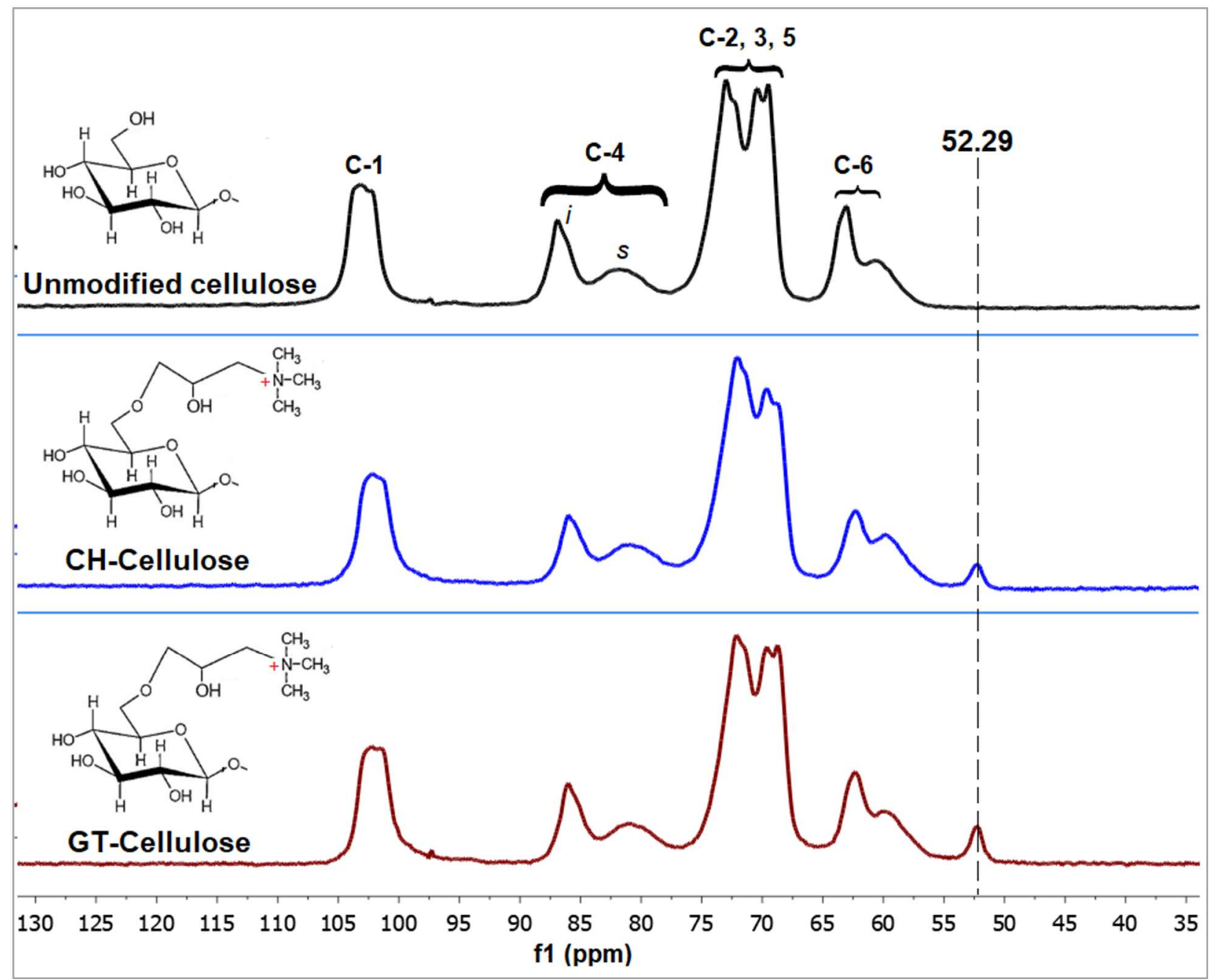

Figure 3: CP-MAS ${ }^{13} \mathrm{C}$ NMR Spectra of unmodified and cationised cellulose, showing crystalline $(i)$ and amorphous $(s)$ regions of $\mathrm{C}-4$.

\subsection{Cr(VI) adsorption performance of cationised cellulose}

The percentage removal of $\mathrm{Cr}(\mathrm{VI})$ by cationised cellulose at $\mathrm{pH} 4$ is presented in Figure 4 . For these experiments, varying amounts of $\mathrm{CH}$-cellulose and GT-cellulose were exposed to $\mathrm{Cr}(\mathrm{VI})$ solutions $\left(0.381 \mathrm{mg} \mathrm{L}^{-1}\right)$ at $\mathrm{pH} 4$ for 240 minutes. The results showed that $\mathrm{Cr}(\mathrm{VI})$ uptake increased with increasing adsorbent concentration and that it was higher for GT-cellulose than $\mathrm{CH}$-cellulose. The increase in $\mathrm{Cr}(\mathrm{VI})$ removal with increasing adsorbent dosage is due to the increase in available binding sites on the adsorbent. Importantly, though, these data suggest that GT-cellulose was a more efficient $\mathrm{Cr}(\mathrm{VI})$ adsorbent than $\mathrm{CH}$-cellulose. This may be explained by differences between the two materials with respect to (i) availability of protonated amine sites based on nitrogen concentration, and (ii) the $\mathrm{pH}_{\mathrm{PZC}}$ of the adsorbents (Table 1). GT-cellulose had a higher concentration of quaternary amines in the matrix, as evidenced by the higher concentration of nitrogen. Further, with a pHPZC of 7.4, most of these amine sites were protonated at the experimental $\mathrm{pH}$ of 4 . In contrast, most sorption sites of $\mathrm{CH}$-cellulose fibres are neutral at $\mathrm{pH} 4$ due to the $\mathrm{pH}_{\mathrm{PZC}}$ of 4.2 of this material. As such, electrostatic attraction between $\mathrm{CH}$-cellulose and $\mathrm{HCrO}_{4}^{-}$ions were limited, hence the low adsorption efficiency. As the adsorption 
efficiency of GT-cellulose became constant above $0.1 \mathrm{~g}$ of adsorbent mass, this was set as the adsorbent concentration for subsequent studies for both materials in order to generate comparable data.
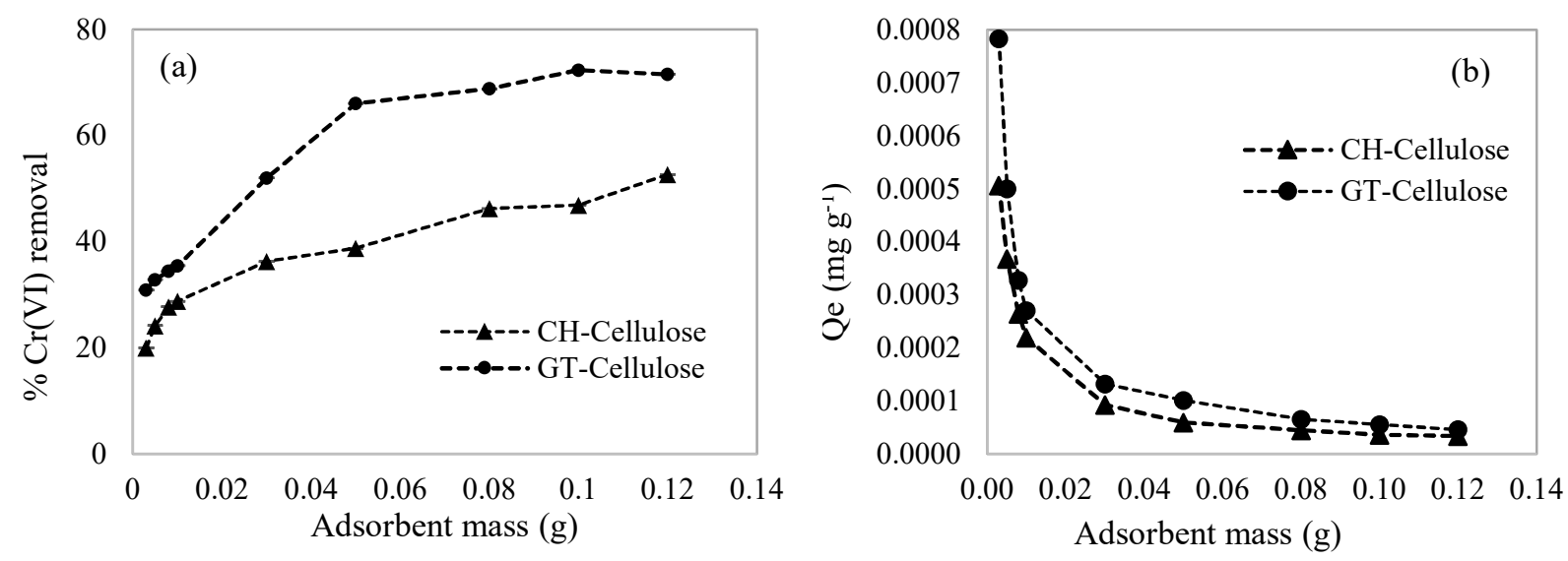

Figure 4: Effect of adsorbent dose on (a) \% Cr(VI) removal by CH-cellulose and GT-cellulose. (b) Experimental qe values. Conditions: $\mathrm{pH}=4,[\mathrm{Cr}(\mathrm{VI})]=0.381 \mathrm{mg} \mathrm{L}^{-1}$, contact time $=240$ minutes.

\subsection{Adsorption kinetics}

The rate of adsorption is one of the most important aspects defining the efficiency of an adsorbent. In this study, the effect of time on the uptake of $\mathrm{Cr}(\mathrm{VI})$ ions by cationised celluloses was investigated at $\mathrm{pH} 4$, using $0.1 \mathrm{~g}$ of adsorbents and $20 \mathrm{~mL}$ of adsorbate $\left(0.381 \mathrm{mg} \mathrm{L}^{-1}\right)$. Adsorption data were then subjected to the pseudo-firstorder, pseudo-second-order and Elovich kinetics models represented by Equations 8, 9 and 10, respectively (Ho and Mckay, 1998).

$\ln \left(q_{e}-q_{t}\right)=\ln \left(q_{e}\right)-k_{1} t$

$\frac{t}{q_{t}}=\frac{1}{k_{2} q_{e}^{2}}+\frac{1}{q_{e}} t$

$q_{t}=\beta \ln (\alpha \beta)+\ln (t)$

Model fit and rate constants were determined from plots of $\ln \left(q_{e}-q_{t}\right)$ versus $t$ for the pseudo-first order model, $t / q_{t}$ against $t$ for the pseudo-second order model, and $q_{t}$ against $\ln (t)$ for the Elovich model. The results show that the rate of $\mathrm{Cr}(\mathrm{VI})$ uptake by cationised cellulose was best fitted by the pseudo-second order model (Table 3), suggesting that chemical sorption was the rate-limiting step of the process. 
Table 3: Kinetics model parameters for the uptake of $\mathrm{Cr}(\mathrm{VI})$ onto cationised cellulose. Conditions: $\mathrm{pH}=4$, $[\mathrm{Cr}(\mathrm{VI})]=0.381 \mathrm{mg} \mathrm{L}^{-1}$, adsorbent mass $=0.1 \mathrm{~g}$.

\begin{tabular}{llll}
\hline Model & Parameter & CH-Cellulose & GT-Cellulose \\
\hline Pseudo-first-order & $k_{1}\left(\mathrm{~min}^{-1}\right)$ & 0.0002 & 0.0007 \\
& $q_{\mathrm{e}}, \mathrm{cal}\left(\mathrm{mg} \mathrm{g}^{-1}\right)$ & 0.0003 & 0.0002 \\
& $q_{\mathrm{e}}, \exp \left(\mathrm{mg} \mathrm{g}^{-1}\right)$ & 0.0008 & 0.0013 \\
& $R^{2}$ & 0.3680 & 0.2065 \\
Pseudo-second-order & $k_{2}\left(\mathrm{~g} \mathrm{mg}^{-1} \mathrm{~min}^{-1}\right)$ & 285.96 & \\
& $q_{\mathrm{e}}, \mathrm{cal}\left(\mathrm{mg} \mathrm{g}^{-1}\right)$ & 0.0008 & 780.16 \\
& $q_{\mathrm{e}}, \exp \left(\mathrm{mg} \mathrm{g}^{-1}\right)$ & 0.0008 & 0.0013 \\
& $R^{2}$ & 0.9993 & 0.0013 \\
& & & 0.9996 \\
Elovich & $\alpha\left(\mathrm{g} \mathrm{mg}^{-1} \mathrm{~min}^{-1}\right)$ & 0.0779 & 0.2537 \\
& $\beta 1 / \mathrm{b}\left(\mathrm{g} \mathrm{mg}^{-1}\right)$ & 15283.58 & 9658.08 \\
& $R^{2}$ & 0.8636 & 0.5653 \\
\hline
\end{tabular}

\subsection{Adsorption isotherms}

Adsorption isotherms explain adsorbate-adsorbent interactions at sorption sites. This information helps to understand sorption mechanisms, as well as for the design of appropriate sorption systems. In order to understand the mechanisms by which $\mathrm{Cr}(\mathrm{VI})$ ions were sorbed to cationised cellulose, experimental sorption data subjected to three isotherm models: Langmuir, Freundlich, and Dubinin-Radushkevich.

The Langmuir isotherm is based on a number of assumptions including a fixed number of sorption sites on an adsorbent surface and a lack of dependence on surface coverage, of the free energy of adsorption. As such, adsorption of an ion to a particular site is independent of whether adjacent sites are occupied by solvent or other adsorbate species. In other words, the driving force for sorption of an ion to an adsorbate-free site is similar to that for adsorption to a nearly filled surface. The assumption of a fixed number of sorption sites means that as more ions sorb to the adsorbent surface and sorption sites decrease, and the tendency of sorption of additional sorbate molecules decreases. Nevertheless, whenever a sorbate molecule sorbs to a site, the free energy is the same as that involved in the formation of previous adsorbate-sorbent bonds (Leckie, J. O. Benjamin, M. M., Hayes, K., Kaufman, G., Altman, 1980).

It is represented by Equation 11 below where $q_{m}$ is the maximum adsorption capacity $\left(\mathrm{mg} \mathrm{g}^{-1}\right)$ and $K_{L}$ is the Langmuir constant which is related to adsorption energy $\left(\mathrm{L} \mathrm{mg}^{-1}\right) . K_{L}$ and $q_{m}$ are determined from a plot of $1 / q_{e}$ versus $1 / C_{e}$.

$\frac{1}{q_{e}}=\left(\frac{1}{q_{m}}\right)+\frac{1}{K_{L} q_{m} C_{e}}$

The Freundlich isotherm (Equation 12) assumes that sorbent sites are heterogeneous in terms of their energies, and that ions can form more than single layer on the sorbent surface. In a qualitative way, $K_{\mathrm{F}}$ is related to the strength of the sorption bond, and $n$ to the distribution of bond strengths (Leckie, J. O. Benjamin, M. M., Hayes, K., Kaufman, G., Altman, 1980). The greater the difference between the $n$ value of a reaction and 1, the wider is the distribution of surface bond energies of sorbate-sorbent interaction for that adsorbent i.e. greater heterogeneity of sorption sites. 
$\log q_{e}=\left(\frac{1}{n}\right) \log C_{e}+\log K_{F}$

An $n<1$, suggests bond energies increasing with adsorption density, which may occur, when interactions between ions sorbed onto of the adsorbent are favourable. Conversely, $n>1$ suggests unfavourable adsorbateadsorbate interactions.

The Dubinin-Radushkevich (D-R) model also assumes multi-layer adsorption, but proceeds from the premise that sorbate molecules bind first to energetically favourable sites, before multilayer adsorption can begin (Hutson and Yang, 1997). It is described by Equation 13 in which $K_{\mathrm{D}-\mathrm{R}},\left(\mathrm{mol}^{2} \mathrm{~J}^{-2}\right)$ is a constant related to the adsorption energy, and $\varepsilon$ is the Polanyi potential. The latter is calculated using Equation (14) in which $R$ is the gas law constant $\left(\mathrm{kJ} \mathrm{mol}^{-1} \mathrm{~K}^{-1}\right)$ and $T$ is the absolute temperature $(\mathrm{K}) . K_{\mathrm{D}-\mathrm{R}}$ and $q_{m}$ can be determined from a plot of $\ln q_{e}$ versus $\varepsilon$.

$\ln q_{e}=\ln q_{m}-K_{D-R} \varepsilon^{2}$

$\varepsilon=R \operatorname{Rln}\left(1+\frac{1}{C_{e}}\right)$

The D-R isotherm also allows for evaluation of the nature of adsorption i.e. by chemisorption or physisorption, based on an evaluation of the mean energy of adsorption $\left(E, \mathrm{~kJ} \mathrm{~mol}^{-1}\right)$ that can be determined using Equation 15 .

$E=\frac{1}{\sqrt{2} K_{D-R}}$

A value of $E<8 \mathrm{~kJ} \mathrm{~mol}^{-1}$ represents physisorption while a value between 8 and $16 \mathrm{~kJ} \mathrm{~mol}^{-1}$ is representative of chemisorption. When $\mathrm{E}$ is $>16 \mathrm{~kJ} \mathrm{~mol}^{-1}$, adsorption is likely dominated by particle diffusion.

Results of model fitting of adsorption data to the three isotherms described above are given in Table 4. Based on the $R^{2}$ values, $\mathrm{Cr}(\mathrm{VI})$ sorption to both cationised cellulose derivatives was best described by the Freundlich and D-R models $\left(R^{2}>0.95\right)$. This suggests that adsorption of $\mathrm{Cr}(\mathrm{VI})$ ions to the surfaces of these sorbents involves binding to energetically heterogeneous sites, and in multiple layers.

Furthermore, as the value of $E$ from the D-R isotherm, was between 8 and $16 \mathrm{~kJ} \mathrm{~mol}^{-1}$ in both cases, this suggests that the binding of $\mathrm{Cr}(\mathrm{VI})$ to surfaces of cationic cellulose involved chemisorption. From the Freundlich isotherm, $n$ was found to be $>1$ for both materials, implying that interactions between sorbed $\mathrm{Cr}(\mathrm{VI})$ on the adsorbent surface were not favourable for adsorption e.g. due to repulsive forces between negatively charged ions. As a result of the anion-anion repulsions, approach of additional anions towards the adsorbate surface was hindered, thus limiting adsorption efficiency of the materials (Hu et al., 2005; Leckie, J. O. Benjamin, M. M., Hayes, K., Kaufman, G., Altman, 1980).

Table 4: Parameters of isotherms for $\mathrm{Cr}(\mathrm{VI})$ adsorption by cellulose modified by CHPTAC and GTMAC.

\begin{tabular}{llll}
\hline Isotherm & Parameter & CH-Cellulose & GT-Cellulose \\
\hline Dubinin-Radushkevich (D-R) & $K_{\mathrm{D}-\mathrm{R},\left(\mathrm{mol}^{2} \mathrm{~J}^{-2}\right)}$ & 0.007 & 0.005 \\
& $q_{m}(\mathrm{cal})\left(\mathrm{mmol} \mathrm{g}^{-1}\right)$ & 0.983 & 1.010 \\
& $E, \mathrm{~kJ} \mathrm{~mol}^{-1}$ & 8.260 & 9.827 \\
& $R^{2}$ & 0.970 & 0.953 \\
& & & \\
Freundlich & $K_{\mathrm{F}}\left(\left(\mathrm{mg} \mathrm{g}^{-1}\right)\left(\mathrm{mg} \mathrm{L}^{-1}\right)^{1 / \mathrm{n}}\right)$ & 1.010 & 1.012 \\
& $n$ & 1.633 & 2.030
\end{tabular}




\begin{tabular}{cccc} 
& $1 / n$ & 0.612 & 0.493 \\
& $R^{2}$ & 0.975 & 0.951 \\
& & & \\
Langmuir & $R^{2}$ & $0.006^{*}$ & $0.507^{*}$ \\
\hline
\end{tabular}

*Parameters not calculated due to the low $R^{2}$ value.

\subsection{Application to AMD- contaminated water}

As GT-cellulose showed greater efficiency for $\mathrm{Cr}(\mathrm{VI})$ removal in synthetic water samples, it was selected to study uptake of $\mathrm{Cr}(\mathrm{VI})$ from AMD-contaminated water. The results of experiments conducted for 240 minutes without any $\mathrm{pH}$ adjustments to the water are presented in Figure 5 below. These data show that $\mathrm{Cr}(\mathrm{VI})$ removal by GT-cellulose decreased from $72 \%$ in single-ion solutions, to $22 \%$ in AMD contaminated water. The data show that this is likely due to competition effects from other ions present in AMD, particularly $\mathrm{Al}$ and Fe. We surmise that because these ions exist at much higher concentrations, they deposit onto cellulose fibres, blocking $\mathrm{Cr}(\mathrm{VI})$ sorption sites on GT-cellulose. This implies that the effective use of cationic cellulose for $\mathrm{Cr}(\mathrm{VI})$ removal would require pre-treatment steps involving removal of $\mathrm{Fe}$ and $\mathrm{Al}$.

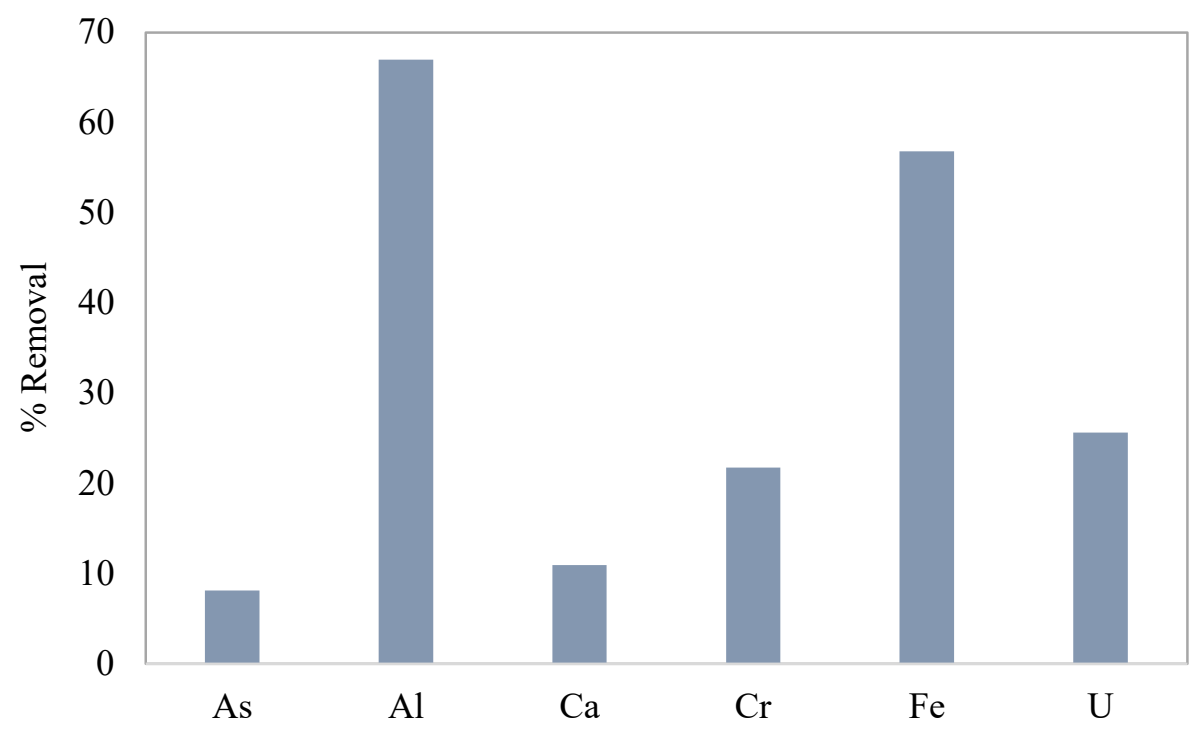

Figure 5: Removal of $\mathrm{Cr}(\mathrm{VI})$ and other ions present in mine drainage contaminated water by GT-cellulose. Conditions: $\mathrm{pH}=2.7$, adsorbent mass $=0.1 \mathrm{~g}$, Volume $=20 \mathrm{~mL}$, contact time $=240$ minutes.

\subsection{Antibacterial activity of cationised cellulose}

The use of cationisation agents as sorbents for water treatment proffers additional benefits beyond the removal of anions due to antimicrobial properties of quaternary ammonium salts (Jennings et al., 2015; Pour et al., 2015). The antimicrobial properties of cationised adsorbents prepared in this study were quantified using E.coli as a model indicator bacteria. Two techniques were employed: cell viability and glutathione loss. The loss of viability by bacterial cells in the presence of quaternary ammonium salts begins when the positively charged heads of the salts bind electrostatically to the phospholipid membranes of bacteria. This results in membranes being disrupted 
or thinned, leakage of cytosolic contents, and destruction of essential gradients, culminating in the death of cells (Jennings et al., 2015).

Cell death may also be via reactive oxidative species (ROS) (Liu et al., 2011). The glutathione test offers an indirect way of measuring ROS production by bacterial cells. Glutathione is present in bacteria as an antioxidant. In the presence of ROS, its thiol groups are oxidised to disulphide bonds. In the glutathione test, Ellman's test is used to test for ROS production by quantifying thiol concentrations. Reduction in glutathione concentration indicates ROS production.

The results of cell viability tests and glutathione oxidation are presented in Table 5. They show that exposure to cationised cellulose reduced the viability of $E$. coli from $\sim 72 \%$ (unmodified cellulose) to $\sim 56 \%$ (GT-cellulose). This confirms the known effects of quaternary ammonium salts and suggests that prepared adsorbents could proffer disinfection advantages. Further, the greater antibacterial activity GT-cellulose implies that antimicrobial efficiency of the adsorbents can be increased by optimisation of cationisation.

Table 5: Loss of viability for E.coli, and glutathione oxidation induced by unmodified cellulose and cationised derivatives.

\begin{tabular}{lll}
\hline & Loss of Viability of $\boldsymbol{E}$. coli cells $(\%)$ & Loss of Glutathione (\%) \\
\hline Control & 0 & 0 \\
Unmodified cellulose & 27.7 & 30.4 \\
CH-cellulose & 34.9 & 30.5 \\
GT-cellulose & 44.5 & 36.9 \\
\hline
\end{tabular}

To further explore the possibility that ROS played a role in cell death, glutathione experiments were conducted. The loss of glutathione, particularly for GT-cellulose, suggests that the presence of cationised cellulose resulted in production of ROS. This implies that cationised cellulose mediated oxidative stress in E. coli. We posit that the loss of cell viability may be due, in part, to oxidation of thiols. Furthermore, this oxidation may be of phospholipids thus compromising membrane structure, but it may also be of cellular components including proteins, lipids and DNA.

\section{Conclusion}

Cellulose cationised using CHPTAC and GTMAC were found to be effective sorbents for the removal of Cr(VI) ions from synthetic and actual samples of mine contaminated water. Cellulose cationised using GTMAC showed greater removal capacities at $\mathrm{pH} 4$, likely due to its higher cationisation efficiency as determined by elemental analysis. The $\mathrm{pH}_{\mathrm{PZC}}$ of materials also influenced $\mathrm{Cr}(\mathrm{VI})$ removal. With a $\mathrm{pH}_{\mathrm{PZC}}$ of 4.2 , the surfaces of CHPTACcationised cellulose were almost all neutrally charged at $\mathrm{pH} 4$ resulting in negligible electrostatic attraction between adsorbent sites and the adsorbate ions. In contrast, GTMAC-cationised cellulose with a pHPZC of 7.4, and was positively charged at the experimental $\mathrm{pH}$ and primed for anion uptake. For both adsorbents, reaction kinetics followed the pseudo-second order model, while isotherms were best described by the Freundlich and Dubinin-Radushkevich models. The adsorbents were also found to have significant antimicrobial properties, inducing the production of reactive oxidative species and reducing the viability of E.coli cells from $\sim 77 \%$ to $\sim 56 \%$. Together, these results suggest that cellulose cationisation can be a useful approach for the development of environmentally-friendly and affordable adsorbents for the removal of $\mathrm{Cr}(\mathrm{VI})$ ions from mine-drainage contaminated water. Further, these adsorbents would offer the additional advantage of disinfection that could be 
useful where the water is also subjected to biological contamination. Nevertheless, pre-treatments to reduce Al and Fe loads would be required in order to increase the adsorbent efficiencies.

Acknowledgements: We thank Dr. Izak Kotze for NMR experiments. AE and JM acknowledge funding from the Royal Society under the FLAIR program, contract FLR $\backslash R 1 \backslash 190087$.

Conflict of interest: The authors declare no conflict of interest.

\section{References}

Acharya, S., Abidi, N., Rajbhandari, R., Meulewaeter, F., 2014. Chemical cationization of cotton fabric for improved dye uptake. Cellulose 21, 4693-4706. https://doi.org/10.1007/s10570-014-0457-2

Alebeid, O.K., Zhao, T., 2016. Simultaneous dyeing and functional finishing of cotton fabric using reactive dyes doped with TiO2 nano-sol. J. Text. Inst. 107, 625-635. https://doi.org/10.1080/00405000.2015.1054209

Anand, A., Unnikrishnan, B., Mao, J., Lin, H., Huang, C., 2018. Graphene-based nano filtration membranes for improving salt rejection, water flux and antifouling - A review. Desalination 429, 119-133. https://doi.org/10.1016/j.desal.2017.12.012

Beck, S., Me, M., Bouchard, J., 2015. General procedure for determining cellulose nanocrystal sulfate half-ester content by conductometric titration 101-116. https://doi.org/10.1007/s10570-014-0513-y

Benhamou, A., Basly, J.P., Baudu, M., Derriche, Z., Hamacha, R., 2013. Amino-functionalized MCM-41 and MCM-48 for the removal of chromate and arsenate. J. Colloid Interface Sci. 404, 135-139. https://doi.org/10.1016/j.jcis.2013.04.026

Benhamou, K., Dufresne, A., Magnin, A., Mortha, G., Kaddami, H., 2014. Control of size and viscoelastic properties of nanofibrillated cellulose from palm tree by varying the TEMPO-mediated oxidation time. Carbohydr. Polym. 99, 74-83. https://doi.org/10.1016/j.carbpol.2013.08.032

Besbes, I., Alila, S., Boufi, S., 2011. Nanofibrillated cellulose from TEMPO-oxidized eucalyptus fibres: Effect of the carboxyl content. Carbohydr. Polym. 84, 975-983. https://doi.org/10.1016/j.carbpol.2010.12.052

Cherian, B.M., Leão, A.L., de Souza, S.F., Thomas, S., Pothan, L.A., Kottaisamy, M., 2010. Isolation of nanocellulose from pineapple leaf fibres by steam explosion. Carbohydr. Polym. 81, 720-725. https://doi.org/10.1016/j.carbpol.2010.03.046

Dindar, M.H., Yaftian, M.R., Rostamnia, S., 2015. Potential of functionalized SBA-15 mesoporous materials for decontamination of water solutions from $\mathrm{Cr}(\mathrm{VI}), \mathrm{As}(\mathrm{V})$ and $\mathrm{Hg}(\mathrm{II})$ ions. J. Environ. Chem. Eng. 3, 986-995. https://doi.org/10.1016/j.jece.2015.03.006

El Achaby, M., Kassab, Z., Barakat, A., Aboulkas, A., 2018. Alfa fibers as viable sustainable source for cellulose nanocrystals extraction: Application for improving the tensile properties of biopolymer nanocomposite films. Ind. Crops Prod. 112, 499-510. https://doi.org/10.1016/j.indcrop.2017.12.049

Etale, A., Nhlane, D., Richards, H., 2020. Graphene oxide nanosheets for treatment of mine-drainage contaminated water: The effect of phosphate functionalisation on U(VI) removal, in: Materials Today Proceedings.

Etale, A., Tutu, H., Drake, D.C., 2015. The effect of silica and maghemite nanoparticles on remediation of $\mathrm{Cu}(\mathrm{II})-$, $\mathrm{Mn}(\mathrm{II})-$ and U(VI)-contaminated water by Acutodesmus sp. J. Appl. Phycol. 28, 251-260.

https://doi.org/10.1007/s10811-015-0555-z

Etale, A., Yalala, B., Tutu, H., Drake, D.C., 2014. Adsorptive removal of mercury from acid mine drainage: a comparison of silica and maghemite nanoparticles. Toxicol. Environ. Chem. 96, 542-554. 
https://doi.org/10.1080/02772248.2014.976223

Eyley, S., Thielemans, W., 2014. Surface modification of cellulose nanocrystals. Nanoscale 6, 7764-7779. https://doi.org/10.1039/c4nr01756k

Fellenz, N., Perez-Alonso, F.J., Martin, P.P., García-Fierro, J.L., Bengoa, J.F., Marchetti, S.G., Rojas, S., 2017. Chromium (VI) removal from water by means of adsorption-reduction at the surface of amino-functionalized MCM-41 sorbents. Microporous Mesoporous Mater. 239, 138-146. https://doi.org/10.1016/j.micromeso.2016.10.012

Foster, E.J., Moon, R.J., Agarwal, U.P., Bortner, M.J., Bras, J., Camarero-espinosa, S., Fox, D.M., Hamad, W.Y., Heux, L., Jean, B., Korey, M., Nieh, W., Ong, K.J., Reid, M.S., Renneckar, S., Roberts, R., Shatkin, J.A., Simonsen, J., Stinson-Bagby, K., Wanasekera, N., Youngblood, J., 2018. Current characterization methods for cellulose nanomaterials. Chem. Soc. Rev. 47, 2609-2679. https://doi.org/10.1039/c6cs00895j

Garside, M., 2020. Chemical fibers global production 2000-2019 [WWW Document]. STATISTA. URL https://www.statista.com/statistics/271651/global-production-of-the-chemical-fiberindustry/\#: :text=Chemical fiber production worldwide\&text=By 2019\%2C some 80.5 million,107.5 million metric tons of (accessed 9.27.20).

Gogoi, H., Leiviskä, T., Rämö, J., Tanskanen, J., 2019. Production of aminated peat from branched polyethylenimine and glycidyltrimethylammonium chloride for sulphate removal from mining water. Environ. Res. 175, 323-334. https://doi.org/10.1016/j.envres.2019.05.022

Gorgieva, S., Vogrinčič, R., Kokol, V., 2019. The Effect of Membrane Structure Prepared from Carboxymethyl Cellulose and Cellulose Nanofibrils for Cationic Dye Removal. J. Polym. Environ. 27, 318-332. https://doi.org/10.1007/s10924-018-1341-1

Hashem, A., El-Shishtawy, R.M., 2001. Preparation and characterization of cationized cellulose for the removal of anionic dyes. Adsorpt. Sci. Technol. 19, 197-210. https://doi.org/10.1260/0263617011494088

Heux, L., Dinand, E., Vignon, M.R., 1999. Structural aspects in ultrathin cellulose microfibrils followed by 13C CPMAS NMR. Carbohydr. Polym. 40, 115-124. https://doi.org/10.1016/S0144-8617(99)00051-X

Ho, Y.S., Mckay, G., 1998. A comparison of chemisorption kinetic models applied to pollutant removal on various sorbents. Trans IChemE 76, 332-340.

Hu, J., Lo, I.M.C., Chen, G., 2005. Fast Removal and Recovery of Cr(VI) Using Surface-Modified Jacobsite (MnFe2O4) Nanoparticles. Langmuir 21, 11173-11179.

Hutson, N.D., Yang, R.T., 1997. Theoretical Basis for the Dubinin-Radushkevitch (D-R) Adsorption Isotherm Equation 195, 189-195.

Jennings, M.C., Minbiole, K.P.C., Wuest, W.M., 2015. Quaternary Ammonium Compounds: An Antimicrobial Mainstay and Platform for Innovation to Address Bacterial Resistance. https://doi.org/10.1021/acsinfecdis.5b00047

Johnston, C.P., Chrysochoou, M., 2012. Investigation of chromate coordination on ferrihydrite by in situ ATR-FTIR spectroscopy and theoretical frequency calculations. Environ. Sci. Technol. 46, 5851-5858. https://doi.org/10.1021/es300660r

Kabengi, N.J., Chrysochoou, M., Bompoti, N., Kubicki, J.D., 2017. An integrated flow microcalorimetry, infrared spectroscopy and density functional theory approach to the study of chromate complexation on hematite and ferrihdyrite. Chem. Geol. 464, 23-33. https://doi.org/10.1016/j.chemgeo.2017.01.017

Kassab, Z., Abdellaoui, Y., Salim, M.H., Bouhfid, R., El, A., Qaiss, K., Achaby, M. El, 2020a. Micro- and nanocelluloses derived from hemp stalks and their effect as polymer reinforcing materials. Carbohydr. Polym. 116506. https://doi.org/10.1016/j.carbpol.2020.116506

Kassab, Z., Boujemaoui, A., Ben Youcef, H., Hajlane, A., Hannache, H., El Achaby, M., 2019. Production of cellulose nanofibrils from alfa fibers and its nanoreinforcement potential in polymer nanocomposites. 
Cellulose 26, 9567-9581. https://doi.org/10.1007/s10570-019-02767-5

Kassab, Z., Kassem, I., Hannache, H., Bouhfid, R., Qaiss, A.E.K., El Achaby, M., 2020b. Tomato plant residue as new renewable source for cellulose production: extraction of cellulose nanocrystals with different surface functionalities. Cellulose 27, 4287-4303. https://doi.org/10.1007/s10570-020-03097-7

Klemm, D., Heublein, B., Fink, H.P., Bohn, A., 2005. Cellulose: Fascinating biopolymer and sustainable raw material. Angew. Chemie - Int. Ed. 44, 3358-3393. https://doi.org/10.1002/anie.200460587

Leckie, J. O. Benjamin, M. M., Hayes, K., Kaufman, G., Altman, S., 1980. Adsorption/Coprecipitation of Trace Elements from Water with Iron Oxyhydroxide 1-270.

Liu, S., Zeng, T.H., Hofmann, M., Burcombe, E., Wei, J., Jiang, R., 2011. Antibacterial Activity of Graphite , Graphite Oxide, Graphene Oxide , and Reduced Graphene Oxide : Membrane and Oxidative Stress 69716980. https://doi.org/10.1021/nn202451x

Liu, W., Yang, L., Xu, S., Chen, Y., Liu, B., Li, Z., Jiang, C., 2018. Efficient removal of hexavalent chromium from water by an adsorption-reduction mechanism with sandwiched nanocomposites. RSC Adv. 8, 15087-15093. https://doi.org/10.1039/c8ra01805g

Mandal, A., Chakrabarty, D., 2011. Isolation of nanocellulose from waste sugarcane bagasse (SCB) and its characterization. Carbohydr. Polym. 86, 1291-1299. https://doi.org/10.1016/j.carbpol.2011.06.030

Martín-Domínguez, A., Rivera-Huerta, M.L., Pérez-Castrejón, S., Garrido-Hoyos, S.E., Villegas-Mendoza, I.E., Gelover-Santiago, S.L., Drogui, P., Buelna, G., 2018. Chromium removal from drinking water by redoxassisted coagulation: Chemical versus electrocoagulation. Sep. Purif. Technol. 200, 266-272. https://doi.org/10.1016/j.seppur.2018.02.014

McCarthy, T., 2010. The decanting of acid mine water in the Gauteng city-region.

Naicker, K., Cukrowska, E., McCarthy, T.S., 2003. Acid mine drainage arising from gold mining activity in Johannesburg, South Africa and environs. Environ. Pollut. 122, 29-40. https://doi.org/10.1016/S02697491(02)00281-6

Newman, R.H., 1999. Estimation of the lateral dimensions of cellulose crystallites using 13C NMR signal strengths. Solid State Nucl. Magn. Reson. 15, 21-29. https://doi.org/10.1016/S0926-2040(99)00043-0

Nhlane, S., Richards, H., Etale, A., 2020. Facile and green synthesis of reduced graphene oxide for remediation of $\mathrm{Hg}(\mathrm{II})$ - contaminated water, in: Materials Today Proceedings.

Odabas, N., Amer, H., Bacher, M., Henniges, U., Potthast, A., Rosenau, T., 2016. Properties of Cellulosic Material after Cationization in Different Solvents. ACS Sustain. Chem. Eng. 4, 2295-2301. https://doi.org/10.1021/acssuschemeng.5b01752

Pour, Z.S., Makvandi, P., Ghaemy, M., 2015. Performance properties and antibacterial activity of crosslinked films of quaternary ammonium modified starch and poly(vinyl alcohol). Int. J. Biol. Macromol. 80, 596-604. https://doi.org/10.1016/j.ijbiomac.2015.07.008

Rashid, S., Dutta, H., 2020. Characterization of nanocellulose extracted from short, medium and long grain rice husks. Ind. Crop. Prod. 154, 112627. https://doi.org/10.1016/j.indcrop.2020.112627

Saha, R., Nandi, R., Saha, B., 2011. Sources and toxicity of hexavalent chromium. J. Coord. Chem. 64, 1782-1806. https://doi.org/10.1080/00958972.2011.583646

Sannino, F., Martino, A. De, Pigna, M., Violate, A., Leo, P. Di, Mesto, E., Capasso, R., 2009. Sorption of arsenate and dichromate on polymerin, $\mathrm{Fe}(\mathrm{OH}) \mathrm{x}$-polymerin complex and ferrihydrite. J. Hazard. Mater. 166, 11741179 .

Sehaqui, H., Mautner, A., Perez De Larraya, U., Pfenninger, N., Tingaut, P., Zimmermann, T., 2016. Cationic cellulose nanofibers from waste pulp residues and their nitrate, fluoride, sulphate and phosphate adsorption properties. Carbohydr. Polym. 135, 334-340. https://doi.org/10.1016/j.carbpol.2015.08.091 
Shateri Khalil-Abad, M., Yazdanshenas, M.E., Nateghi, M.R., 2009. Effect of cationization on adsorption of silver nanoparticles on cotton surfaces and its antibacterial activity. Cellulose 16, 1147-1157. https://doi.org/10.1007/s10570-009-9351-8

Silvério, H.A., Flauzino Neto, W.P., Dantas, N.O., Pasquini, D., 2013. Extraction and characterization of cellulose nanocrystals from corncob for application as reinforcing agent in nanocomposites. Ind. Crops Prod. 44, 427436. https://doi.org/10.1016/j.indcrop.2012.10.014

Smith, E., Ghiassi, K., 2006. Chromate Removal by an Iron Sorbent: Mechanism and Modeling. Water Environ. Res. 78, 84-93. https://doi.org/10.2175/106143005x84558

Sugiyama, J., Vuong, R., Chanzy, H., 1991. Electron Diffraction Study on the Two Crystalline Phases Occurring in Native Cellulose from an Algal Cell Wall. Macromolecules 24, 4168-4175. https://doi.org/10.1021/ma00014a033

Tutu, H., 2006. Determination and geochemical modelling of the dispersal of uranium in gold-mine polluted land on the Witwatersrand Basin. University of the Witwatersrand.

Udoetok, I.A., Dimmick, R.M., Wilson, L.D., Headley, J. V., 2016a. Adsorption properties of cross-linked celluloseepichlorohydrin polymers in aqueous solution. Carbohydr. Polym. 136, 329-340. https://doi.org/10.1016/j.carbpol.2015.09.032

Udoetok, I.A., Wilson, L.D., Headley, J. V., 2016b. Quaternized cellulose hydrogels as sorbent materials and pickering emulsion stabilizing agents. Materials (Basel). 9, 6-8. https://doi.org/10.3390/ma9080645

Wang, X., Li, H., Cao, Y., Tang, Q., 2011. Cellulose extraction from wood chip in an ionic liquid 1-allyl-3methylimidazolium chloride (AmimCl). Bioresour. Technol. 102, 7959-7965. https://doi.org/10.1016/j.biortech.2011.05.064

WHO, 2003. Guidelines for Drinking-water Quality.

Wickholm, K., Larsson, P.T., Iversen, T., 1998. Assignment of non-crystalline forms in cellulose I by CP/MAS 13C NMR spectroscopy. Carbohydr. Res. 312, 123-129. https://doi.org/10.1016/S0008-6215(98)00236-5

Zaman, M., Xiao, H., Chibante, F., Ni, Y., 2012. Synthesis and characterization of cationically modified nanocrystalline cellulose. Carbohydr. Polym. 89, 163-170. https://doi.org/10.1016/j.carbpol.2012.02.066

Zhao, F., Repo, E., Song, Y., Yin, D., Hammouda, S. Ben, Chen, L., Kalliola, S., Tang, J., Tam, K.C., Sillanpää, M., 2017. Polyethylenimine-cross-linked cellulose nanocrystals for highly efficient recovery of rare earth elements from water and a mechanism study. Green Chem. 19, 4816-4828. https://doi.org/10.1039/c7gc01770g

Zou, W., Bai, H., Zhao, L., Li, K., Han, R., 2011. Characterization and properties of zeolite as adsorbent for removal of uranium(VI) from solution in fixed bed column. J. Radioanal. Nucl. Chem. 288, 779-788.

https://doi.org/10.1007/s10967-011-1026-x 